Minia J. of Agric. Res. \& Develop.

Vol. (41), No.1, pp13-23., 2021

FACULTY OF AGRICULTURE

\title{
PHYSIOLOGICAL STUDIES ON ROOTING OF OFFSHOOTS IN DRY DATE PALM SAKKOUTI CULTIVAR.
}

\author{
Wassel, A, $H^{1}$, Gadalla, E. $G^{2}$ and Taha, M.H ${ }^{2}$ \\ ${ }^{1}$ Minia University. Faculty of Agriculture \\ ${ }^{2}$ Central Laboratory for Research and Development of Date Palm, Agriculture Research Center \\ (ARC) \\ *Correspondence: E-mail:mamdouhhaseeb27@gmail.com
}

\section{ABSTRACT:}

Received: 15June (2021) Accepted: 5Augast (2021)

The present investigation was carried out during two successive seasons 2016/2017 and 2017/2018 to determine the impact of two growth regulators (IAA and IBA) either solely or in combination as well as studying the effect of offshoot weight on rooting of date palm offshoots $\mathrm{Cv}$. Sakkouti. The best results concerning the number of roots, root dimeter, the length of longer roots and new leaves were resulted from treating offshoots by IAA or IBA each at $4000 \mathrm{ppm}$ or in combination between them each at $2000 \mathrm{ppm}$. The highest weight of offshoots $(8-10 \mathrm{~kg})$ presented the best results concerning any investigated parameter.

Key words: Date palm, Off-shoots, Growth regulators (Indole butyric acid IBA -Indole acetic acid IAA), Rooting

\section{INTRODUCTION}

Date palm is one of the oldest fruit crops mainly cultivated in North Africa, Middle East, Near East of Asia and some dispersed areas of Europe and America (Zaid, 2002; Hodel and Johnson, 2007; Haider et al., 2013). The date is the most important agricultural crop in the area and provides food and income to the majority of the inhabitants. There are three techniques to propagate date palm: Seed propagation, offshoot propagation (traditional methods), and the recently developed tissue culture techniques. Offshoot propagation also called vegetative propagation. Date palm (Phoenix dactylifera L.) is propagated traditionally by offshoots which are produced in a limited number in a palm tree. Success of establishment of date palm offshoots is different between date palm cultivars. It depends on some factors such as offshoot weight, age, Sultan (1999) reported that the 
highest weight of offshoots gave the highest rooting percentage and number of roots per offshoot, while small offshoots gave the lowest rooting percentage and numbers of roots (Alihouri and Dialami 2010) .Propagation offshoots in date palms faces difficulty rooting after the process of separating them from the mother plant because of their root system characteristics and the ability of their trunks to store water and carbohydrates (Tomlinson, 1990). Development of the root structure plays critical role in survival and growth of the date palm. Most of the palm species produce adventitious roots that originate from the root initials present on trunk (Day et al., 2009). Rooting capacity has been correlated with some endogenous substances such as carbohydrate content (Rahnama and Rahkhodaei, 2013). Many natural and synthetic compounds exhibit auxin-like activity in bioassays, indole-3-acetic acid (IAA) is recognized as the key auxin in most plants. IAA is synthesized both from tryptophan (Trp) using Trp- independent pathways and from an indole Trp precursor via Trp-independent pathways; Plants can also obtain IAA by b-oxidation of indole-3butyric acid (IBA), a second endogenous auxin, or by hydrolyzing IAA conjugates, in which IAA is linked to amino acids, sugars or peptides (Woodward and Bertel, 2005). Auxins play a vital role in encouraging the development of the root system. The phytohormone auxin is critical for plant growth and orchestrates many developmental processes such as IBA and IAA Auxins have been implicated in the adventitious root initiation of several plant species. (Gasper and Hodinger, 1989). Indole butyric acid (IBA) is a growth regulator that stimulates root formation by reducing the time needed for the emergence of adventitious roots in different types of plants as well as improving the number and length of roots as it encourages splitting and elongation the primary roots cells. (Hunt et al. 2011) However, there was no agreement on the effect of auxins application on root formation of date palm offshoots. Auxin treatment was found to increase rooting effectively on the aerial offshoots (Gupta and Godara, 1984).No such effect was found in other reports (Reuveni et al 1972). It has been reported that beside the suitable auxin content of the plant material, there are several other rooting co-factors which occur naturally in the cuttings of several plant species. These co-factors appear to act synergistically with auxins in the root initiation process of hard-to-root cuttings (Hess, 1968; James et aI., 1980; James and Thurbon, 1981; Jones and Hopgood, 1979). This study was designed to investigate the effect of growth regulators indole-acetic acid (IAA) and indole-butyric acid (IBA) as well as weight of date palm offshoots Cv. Sakkouti on rooting.

\section{MATERIALS AND METHODS}

The present investigation was carried out during the two successive seasons (2016-2017 and 2017 -2018 in the greenhouse of the Central Laboratory for Date Palm Research and Development (CLDPRD) Aswan governorate to study the effect of different growth regulators and offshoots weight on rooting of 
dry date palm Cv. Sakkouti. The un-rooted offshoots (48) were purshaed from a farm in Shark AlOwainat Egypt.

\section{- Chemicals:}

- Growth regulators used in this study included Indole acetic acid (IAA) and Indole butyric acid (IBA) which were obtained from Sigma Company.

- fungicide (Rizolex-T 50 \% wp) was obtained from Sometomo Chemicals Limited -Japan.

- Agriculture supplies such as (sacks, burlap fabric and car lubricant were obtained from local market.

\section{EXPERIMENTAL METHOD}

\section{1-Preparation of offshoots}

The selected offshoots were three years old and detached carefully from their mother plants which were more than ten years old. They were healthy and free from diseases and insects. Offshoots were cleaned from the base of leaves, leaf coleoptiles, and old roots, while the top of leaves were shortened and tied with a rope. The offshoots were divided into two groups, according to their weight, the first one was 4-7 kgs while the second one weighed from 8-10 kgs.

\section{2-Preparation of growth regulators.}

-Growth regulators powder such as IAA and IBA were dissolved in Ethyl alcohol $70 \%$ then completed with water till reached 1000,2000,3000,4000 ppm per each. Growth regulators were used solely or in combinations.

\section{3-Treatments with growth regulators.}

Offshoot (48) were dipped in different growth regulators solution for 20 minutes then dipped in fungicide (rizolex) solution $(0.3 \%)$ for 5 minutes, then the separation area was covered by car lubricant then planted in sacks with sandy soil and covered with burlap fabric to protect them. (keep). Treatments were carried out as follows, each was of three replicates.

\section{TREATMENTS}

T1- Control dipped in distillate Water.

T2- IAA at a concentration of $3000 \mathrm{ppm}$.

T3- IAA at a concentration of $4000 \mathrm{ppm}$.

T4 - IBA at a concentration of $3000 \mathrm{ppm}$. 
T5- IBA at a concentration of $4000 \mathrm{ppm}$.

T6- IBA at a conc of $1000 \mathrm{ppm}+$ IAA at a conc of $2000 \mathrm{ppm}$.

T7- IBA at a conc of $2000 \mathrm{ppm}+\mathrm{IAA}$ at a conc of $1000 \mathrm{ppm}$.

T8- IBA at a conc of 2000 of ppm + IAA at a conc of 2000 ppm.

\section{Data transcription:}

After 6 months form cultivation the following data were recorded: -

1-Number of new roots, were counted by estimating the average number of roots per offshoot.

2-Root diameter, was carried out by using vernier caliper.

3 - Length of longer root. was estimated in centimeter.

4- Number of new leaves, were counted by estimating the average number of new leaves/offshoots.

\section{-Statistical Analysis}

Data obtained were subjected to the analysis of variances of randomized complete design as recommended by Snedecor and Cochran (1989). LSD at $0.05 \%$ level of significance was used to compare between means according to Steel and Torrie (1980).

\section{RESULTS AND DISCUSSIONS}

-The effect of the two growth regulators Indole acetic acid (IAA) and Indole butyric acid (IBA) as well as the offshoots weight on the behavior of dry date palm Cv Sakkouti could be summarized under the following main topics: -

1-Effect of the Indole acetic acid (IAA) and Indole butyric acid (IBA) as well as the offshoots weight on the root number of dry date palm Cv Sakkouti during 2016/2017-2017/2018 seasons.

In the first experimental season (2016/2017) results Table 1 showed that using IAA or IBA either solely or in combination at the highest concentration $(4000 \mathrm{ppm})$ were of more effective on the number of roots per offshoots since this was presented by 19.33 and 21.00 for Indole acetic acid (IAA) and Indole butyric acid (IBA), respectively (Table 1). Results in the same Table. further showed that the best combination treatment in this concern was of that included IAA or IBA each at 2000 ppm since this presented 31.00 and 62,00 root per offshoot weighing 4-7 $\mathrm{kg}$ or 8-10 $\mathrm{kg}$ respectively (Table 1). 
Regarding the effect offshoots weight, data indicated that the highest weight of offshoots ranged between $(8-10 \mathrm{~kg})$ produced the highest value of root number (18.37) root / offshoots compared was (10.45) or offshoots weighed $(4-7 \mathrm{~kg})$.

Concerning the interaction between growth regulator treatments and offshoots weight results showed that the highest significant value of root number (62.00) was observed when using offshoots weighted 8-10 kg treated with IBA plus IAA each at a concentration of $2000 \mathrm{ppm}$. While this value of root number was (31.00) when using the same treatment applied to offshoots weighed from $4-7 \mathrm{~kg}$. This treatment was of significant effect compared with that of any other treatment included in this experiment.

In the second experimental season the data concerning the effect of growth regulators, offshoots weight and the interaction between them took similar trend to that presented in the first experimental season (Table 2).

These results are in agreement with those obtained by, AL-NAJM (2009), Alihouri and Dialami, 2010; Hunt et al. (2011); Darwesh et al and (2013), Haseeb et al. (2016). Whom indicated that IAA and IBA were effective in rooting offshoots date palm. Our results are also similar to those mentioned by Sultan (1999), Abdel-Hameed (2008) whom indicated that the weight offshoot clearly influenced the number of roots per offshoot.

Table (1): Effect of the Indole acetic acid (IAA) and Indole butyric acid (IBA) as well as the offshoots weight on the root number of dry date palm Cv Sakkouti during the first experimental season $2016 / 2017$.

\begin{tabular}{lccc}
\hline Parameter & \multicolumn{3}{c}{ root numbers } \\
\hline Treatments $(\mathbf{p p m})$ Weights $(\mathbf{k g s})$ & Weight $(\mathbf{4 - 7} \mathbf{~ K g})$ & Weight 8-10 Kg) & Means \\
\hline T1- Control & & 0.00 & 0.00 \\
T2 IAA 3000 ppm & 0.00 & 11.33 & 10.50 \\
T3 - IAA 4000 ppm & 9.67 & 19.33 & 19.33 \\
T4 - IBA 3000 ppm & 19.33 & 13.00 & 8.83 \\
T5 - IBA 4000 ppm & 4.67 & 29.67 & 21.00 \\
T6- IBA 1000 ppm + IAA 2000 ppm & 12.33 & 7.33 & 6.67 \\
T7- IBA 2000 ppm + IAA 1000 ppm & 6.00 & 4.33 & 2.50 \\
T8- IBA 2000 ppm + IAA 2000 ppm & 0.67 & 62.00 & 46.50 \\
Total means & 31.00 & $\mathbf{1 8 . 3 7}$ & \\
\hline LSD at $0.05 \% \mathrm{~A}=9.37 \mathrm{~B}=4.68 \mathrm{AB}=13.25$ & $\mathbf{1 0 . 4 5}$ & \\
\hline
\end{tabular}


Table(2): Effect of the Indole acetic acid (IAA) and Indole butyric acid (IBA) as well as the offshoots weight on the root number of dry date palm Cv Sakkouti during the second experimental season $2017 / 2018$.

\begin{tabular}{lccc}
\hline Parameter & \multicolumn{2}{c}{ root numbers } \\
\hline Treatments (ppm) Weights (kgs) & Weight (4-7 Kg) & Weight 8-10 Kg) & Means \\
\hline T1- Control & & & \\
T2 IAA 3000 ppm & 0.33 & 0.00 & 0.17 \\
T3 - IAA 4000 ppm & 8.67 & 10.67 & 9.67 \\
T4 - IBA 3000 ppm & 13.33 & 23.67 & 18.50 \\
T5 - IBA 4000 ppm & 5.00 & 10.00 & 7.50 \\
T6- IBA 1000 ppm + IAA 2000 ppm & 7.67 & 24.33 & 16.00 \\
T7- IBA 2000 ppm + IAA 1000 ppm & 5.00 & 5.33 & 5.17 \\
T8- IBA 2000 ppm + IAA 2000 ppm & 2.33 & 7.67 & 5.00 \\
Total means & 27.67 & 68.67 & 48.17 \\
\hline
\end{tabular}

LSD at $0.05 \% \mathrm{~A}=6.64 \mathrm{~B}=3,32 \mathrm{AB}=9.39$

2-Effect of the Indole acetic acid (IAA) and Indole butyric acid (IBA) as well as the offshoots weight on the root diameter of dry date palm Cv Sakkouti during 2016/2017-2017/2018 seasons.

The data concerning the effect of IAA, IBA and offshoots weight on the root diameter of Sakkouti date palm Cv during 2016/2017-2017/2018 are presented in Tables (3) and (4).

Results showed that using IAA or IBA each at $4000 \mathrm{ppm}$ gave the highest root diameter in the two experimental seasons. At the same time using IBA at $2000 \mathrm{ppm}$ plus IAA at $2000 \mathrm{ppm}$ gave similar results to the above-mentioned treatment with only one exception in the first experimental season. Results also indicated the highest weight of offshoots $(8-10 \mathrm{~kg})$ were more effective than the other one $(4-7 \mathrm{~kg})$ concerning their influence on root diameter.

The interaction between growth regulators and offshoot weight showed that all treatments were of significant positive effect concerning their influence on the root diameter of Sakkouti date palm Cv. compared with the control with only one exception.

Our results are in accordance with those obtained by Abdel-Hameed (2008), EL-Kosary et al (2009) whom found that treatment with IBA had increased root diameter. In addition, Mansour and Khalil (2019) confirmed the previous results. 
Table (3): Effect of the Indole acetic acid (IAA) and Indole butyric acid (IBA) as well as the offshoots weight on the root diameter of dry date palm Cv Sakkouti during the first experimental season 2016/2017.

\begin{tabular}{lccc}
\hline Parameter & \multicolumn{3}{c}{ root diameter } \\
\hline Treatments (ppm) Weights $(\mathbf{k g s})$ & Weight $(\mathbf{4 - 7} \mathbf{~ K g})$ & Weight 8-10 Kg) & Means \\
\hline T1- Control & & & \\
T2 IAA 3000 ppm & 0.00 & 0.00 & 0.00 \\
T3 - IAA 4000 ppm & 1.67 & 2.00 & 1.83 \\
T4 - IBA 3000 ppm & 2.33 & 2.67 & 2.50 \\
T5 - IBA 4000 ppm & 2.17 & 2.33 & 2.25 \\
T6- IBA 1000 ppm + IAA 2000 ppm & 2.33 & 2.67 & 2.50 \\
T7- IBA 2000 ppm + IAA 1000 ppm & 2.00 & 1.83 & 1.92 \\
T8- IBA 2000 ppm + IAA 2000 ppm & 0.67 & 3.00 & 1.83 \\
Total means & 2.00 & 2.33 & 2.17 \\
\hline
\end{tabular}

LSD at $0.05 \% \mathrm{~A}=0.68 \mathrm{~B}=0.34 \mathrm{AB}=0.96$

Table 4: Effect of the Indole acetic acid (IAA) and Indole butyric acid (IBA) as well as the offshoots weight on the root diameter of dry date palm Cv Sakkouti during the second experimental season 2017/2018.

\begin{tabular}{lccc}
\hline Parameter & \multicolumn{3}{c}{ root diameter } \\
\hline Treatments (ppm) Weights (kgs) & Weight (4-7 Kg) & Weight 8-10 Kg) & Means \\
\hline T1- Control & 0.33 & 0.00 & 0.17 \\
T2 IAA 3000 ppm & 1.67 & 2.00 & 1.83 \\
T3 - IAA 4000 ppm & 2.67 & 2.67 & 2.67 \\
T4 - IBA 3000 ppm & 1.67 & 2.67 & 2.17 \\
T5 - IBA 4000 ppm & 2.33 & 2.67 & 2.50 \\
T6- IBA 1000 ppm + IAA 2000 ppm & 1.67 & 2.00 & 1.83 \\
T7- IBA 2000 ppm + IAA 1000 ppm & 1.67 & 2.67 & 2.17 \\
T8- IBA 2000 ppm + IAA 2000 ppm & 2.67 & 2.67 & 2.67 \\
Total means & $\mathbf{1 . 8 3}$ & $\mathbf{2 . 1 6}$ & \\
\hline
\end{tabular}

LSD at $0.05 \% \mathrm{~A}=0.73 \mathrm{~B}=0.36 \mathrm{AB}=1.03$

3-Effect of the Indole acetic acid (IAA) and Indole butyric acid (IBA) as well as the offshoots weight on length of longer root of dry date palm Cv Sakkouti during 2016/2017-2017/2018 seasons.

Data concerning the effect of IAA or IBA either separately or in combination as well as offshoots weight on the length of longer roots are presented in Tables (5) and (6)

It is clear from the obtained data that IAA or IBA each at a concentration of $4000 \mathrm{ppm}$ were very effective in increasing the length of the root tables (5) and (6). Results in the same Table also indicated that IAA at $2000 \mathrm{ppm}$ plus IBA at the same concentration gave the highest length of roots this was proved statically compared with the control and the other treatments with only one exception. 
Results in the same Table also indicated that the highest weight of offshoots $(8-10 \mathrm{~kg})$ gave the longest roots compared with the other weight $(4-7 \mathrm{~kg})$. These finding are in agreement with those of Nasir (1996) EL-Kosary et al (2009), Darwesh et al, (2013) and Mansour and Khalil (2019), who reported that the root length was increased by increasing IBA concentration.

Table (5): Effect of the Indole acetic acid (IAA) and Indole butyric acid (IBA) as well as the offshoots weight on the length of longer root of dry date palm Cv Sakkouti during the first experimental season 2016/2017.

\begin{tabular}{lccc}
\hline Parameter & \multicolumn{2}{c}{ length of longer root } \\
\hline Treatments (ppm) Weights (kgs) & Weight (4-7 Kg) & Weight 8-10 Kg) & Means \\
\hline T1- Control & & & \\
T2 IAA 3000 ppm & 0.00 & 0.00 & 0.00 \\
T3 - IAA 4000 ppm & 7.00 & 6.33 & 6.67 \\
T4 - IBA 3000 ppm & 10.00 & 29.00 & 31.00 \\
T5 - IBA 4000 ppm & 10.67 & 15.67 & 12.83 \\
T6- IBA 1000 ppm + IAA 2000 ppm & 17.67 & 22.67 & 16.67 \\
T7- IBA 2000 ppm+ IAA 1000 ppm & 4.00 & 14.67 & 16.17 \\
T8- IBA 2000 ppm + IAA 2000 ppm & 12.00 & 14.00 & 9.00 \\
Total means & $\mathbf{1 1 . 7 9}$ & 34.33 & 23.17 \\
\hline
\end{tabular}

LSD at $0.05 \% \mathrm{~A}=12.51 \mathrm{~B}=6.25 \mathrm{AB}=17.6$

Table 6: Effect of the Indole acetic acid (IAA) and Indole butyric acid (IBA) as well as the offshoots weight on the length of longer root of dry date palm Cv Sakkouti during the first experimental season 2017/2018.

\begin{tabular}{lccc}
\hline Parameter & \multicolumn{3}{c}{ length of longer root } \\
\hline Treatments $(\mathbf{p p m})$ Weights $(\mathbf{k g s})$ & Weight $\mathbf{( 4 - 7} \mathbf{~ K g})$ & Weight 8-10 Kg) & Means \\
\hline T1- Control & & & \\
T2 IAA 3000 ppm & 1.00 & 0.00 & 0.50 \\
T3 - IAA 4000 ppm & 10.33 & 9.00 & 9.67 \\
T4 - IBA 3000 ppm & 12.00 & 17.00 & 14.50 \\
T5 - IBA 4000 ppm & 8.67 & 13.33 & 11.00 \\
T6- IBA 1000 ppm + IAA 2000 ppm & 9.33 & 27.67 & 18.50 \\
T7- IBA 2000 ppm + IAA 1000 ppm & 9.33 & 14.00 & 11.67 \\
T8- IBA 2000 ppm + IAA 2000 ppm & 4.33 & 14.33 & 9.33 \\
Total means & 10.67 & 43.67 & 27.17 \\
\hline \multicolumn{2}{c}{$\mathbf{8 . 2 0}$} & $\mathbf{1 7 . 3 7}$ & \\
\hline
\end{tabular}

4-Effect of the Indole acetic acid (IAA) and Indole butyric acid (IBA) as well as the offshoots weight on number of new leaves of dry date palm Cv Sakkouti during 2016/2017-2017/2018 seasons Concerning the effect of IAA and IBA or offshoots weight or the combination between them, results showed that in the two experimental seasons the more effective treatments were obtained from using IBA or IAA at the concentration at $4000 \mathrm{ppm}$ Tables (7) and (8). Results in the same Tables also declared that IBA plus IAA each at $2000 \mathrm{ppm}$ was of positive effect on the number of new leaves per offshoots .data 
furthermore the showed that number of new leaves increased positively by increasing the weight of offshoots. Since 8-10 kgs offshoots were of more pronounced effect than did 4-7 kgs in this concern. The difference between them was proved statically in the two experimental seasons.

These results are supported by the findings of Reja, (2007) EL-Kosary et al (2009) and Darwesh et $\boldsymbol{a l}$, (2013) who declared that number of new leaves were significantly increased by increasing offshoot weight. and IBA concentration.

Table (7): Effect of the Indole acetic acid (IAA) and Indole butyric acid (IBA) as well as the offshoots weight on number of new leaves of dry date palm Cv Sakkouti during the first experimental season 2016/2017.

\begin{tabular}{|c|c|c|c|}
\hline \multirow[t]{2}{*}{ Parameter } & \multicolumn{2}{|c|}{ number of new leaves } & \multirow{3}{*}{ Means } \\
\hline & Weight (4-7 Kg) & Weight 8-10 Kg) & \\
\hline Treatments (ppm) Weights (kgs) & & & \\
\hline T1- Control & 0.00 & 0.00 & 0.00 \\
\hline T2 IAA 3000 ppm & 3.00 & 3.00 & 3.00 \\
\hline T3 - IAA 4000 ppm & 3.00 & 4.33 & 3.67 \\
\hline T4 - IBA 3000 ppm & 2.33 & 3.33 & 2.83 \\
\hline T5 - IBA 4000 ppm & 3.00 & 4.33 & 3.67 \\
\hline T6- IBA 1000 ppm + IAA 2000 ppm & 3.00 & 3.33 & 3.17 \\
\hline T7- IBA 2000 ppm + IAA 1000 ppm & 1.00 & 3.00 & 2.00 \\
\hline T8- IBA 2000 ppm + IAA 2000 ppm & 2.00 & 4.00 & 3.00 \\
\hline Total means & 2.16 & 3.16 & \\
\hline
\end{tabular}

Table (8): Effect of the Indole acetic acid (IAA) and Indole butyric acid (IBA) as well as the offshoots weight on number of new leaves of dry date palm Cv Sakkouti during the second experimental season $2017 / 2018$.

\begin{tabular}{lccc}
\hline Parameter & \multicolumn{3}{c}{ number of new leaves } \\
\hline Treatments (ppm) Weights $(\mathbf{k g s})$ & Weight $(\mathbf{4 - 7} \mathbf{~ K g})$ & Weight 8-10 Kg) & Means \\
\hline T1- Control & & & \\
T2 IAA 3000 ppm & 0.00 & 0.33 & 0.17 \\
T3 - IAA 4000 ppm & 2.33 & 2.67 & 2.50 \\
T4 - IBA 3000 ppm & 3.00 & 3.33 & 3.17 \\
T5 - IBA 4000 ppm & 2.00 & 3.00 & 2.50 \\
T6- IBA 1000 ppm + IAA 2000 ppm & 2.67 & 4.33 & 3.50 \\
T7- IBA 2000 ppm + IAA 1000 ppm & 3.33 & 3.00 & 3.17 \\
T8- IBA 2000 ppm + IAA 2000 ppm & 1.33 & 3.33 & 2.33 \\
Total means & 2.33 & 5.33 & 3.83 \\
\hline \multicolumn{4}{c}{ LSD at $0.05 \% \mathrm{~A}=0.76 \mathrm{~B}=0.38 \mathrm{AB}=1.07$} \\
\hline
\end{tabular}

On the light of the present results, one can state that using IAA or IBA each at $4000 \mathrm{ppm}$ or using the combination between them each at 2000 ppm was significantly effective in rooting the offshoots of Sakkouti dry date palm Cv. 


\section{REFERENCES}

Abdel-Hameed, A. A. (2008). Propagation of Zaghloul Date Palm Using Small Offshoots. Ph.D. Thesis, Faculty of Agriculture, Cairo University, Egypt.

Alihouri, M; and Dialami, H. (2010). Effect Of Offshoot Weight On Establishment And Vegetative Growth In'sayar'date Palm. In Iv International Date Palm Conference 882 (Pp. 755-759).

AL-NAJM, A. R. (2009). Effect of Indole butyric acid and Indole-3-acetic acid on of root initiation date palm (Phoenix dactylifera) cv Hillawi. Basrah Journal For Date Palm Research, 8(1), 13-20.

Darwesh, R. S.; Madbolly, E. A. and Gadalla, E. G.(2013). Impact of Indole Butyric Acid and Paclobutrazol on rooting of Date Palm (Phoenix dactylifera L.) offshoots cultivar Zaghloul. Journal of Horticultural Science \& Ornamental Plants 5 (3): 145-150.105.

Day, S.D ; Watson G; Wiseman P.E. and Harris J.R. (2009). Causes and consequences of deep structural roots in urban trees: From nursery production to landscape establishment. Arboriculture and Urban Forestry, 35: 182 - 191.

El-Kosary, 'S.; Shaheen, M.A. ; Rizk, S.A.Y. and Abdel-Hameed A.A.(2009) Rooting Light Weight Offshoots of Zagloul Date Palm Using Hydroponics Technique Journal of Horticultural Science \& Ornamental Plants 1 (3): 68-78

GASPER, T. and HODINGER, M. (1989). Auxin metabolism during rooting. In adventitious root formation in cuttings. T.A. DAVIS, B.E. HAISSING and N. SANKHLA, eds. Portland, Oreg., Dioscorides Press.

Gupta, O. P. and Godara, N. R.( 1984). Rooting in aerial suckers of date palm. Haryana Agri. Univ. J. Res., 14 (1): 82-84.

Haider, M.S; Khan, I.A. ; Naqvi, S.A; Jaskani M.J and Khan, R.W. (2013). Fruit developmental stages effects on biochemical attributes in date palm. Pak. J. Agri. Sci. 50: 577-583.

Haseeb, G. M. M., El-Kosary, S. E., Abd Elkareem, H. A., and Bakir, M. A. M. (2016). Induction of roots on young date palm offshoots using growth regulators injection. In VI International Symposium on Tropical and Subtropical Fruits 1216 (pp. 115-126).

Hess,C.E.(1968). Internal and external factors regulating root initiation." In root growth: Proc. 1Sth Easter School. In Agriculture Science, Dniv. of Nottingham, London : Butterworth.

Hodel, D.R; Johnson, D.V; (2007). Imported and American Varieties of Dates in the United States. University of California, Agriculture and Natural Resources, $112 \mathrm{pp}$

Hunt, M.A; Trueman, S.J. and Rasmussen, A. (2011). Indole-3-butyric acid accelerates adventitious root formation and impedes shoot growth of Pinus elliottii var. elliottiix P. caribaea var. hondurensis cuttings. New Forests, 41(3): 349-360.

James, D.J; Kright, V. H. and Thurbon, I.U. (1980). Micropropagation of red rasberry and the influence of floroglucinal. Scient. Hort. 12: 313 - 319.

James,D.J. and Thurbon, I.J. (1981). Shoot and root initiation in vitro in the apple rootstocks M 9 and the promotive effects ofphloroglucinal. J. Hort. Sci. 56:15-20.

Jones,O.P. and Hopgood, M.E. (1979). The successful propagation in vitro of two rootstocks of prunes: the plum rootstock Pixy (P. insititia) and the cherry rootstock F 12/1 (P. avium). J. Hort. Sci. 54:63-6.

Mansour, H. A. and Khalil, N. H. (2019). Effect of wounding and iba on rooting of aerial and ground offshoots of date palm phoenix dactylifera 1. medjool cultivar. plant archives, 19(2), 685-689. 
Nasir, M. J. 1996. Effect of IBA on rooted and un-rooted offshoots of date palm (Phoenix dactylifera L.) cv. Hillawii. M.Sc. Thesis, Dept. Hort., Univ. Agric. Faisalabad- Pakistan.

Rahnama, A. A; and Rahkhodaei, E. (2013). Offshoots weight and disinfection on Medjool Date palm survival rate. International Journal of Agriculture and Crop Sciences (IJACS), 5(16), 1784-1788.

Reja, T. H. (2007). Affection of Some treatment on rooting of small attached date palm (phoenix dactylifera l.) offshoots (braim and khastawi cvs). Anbar Journal of Agricultural Sciences, 5(1), 149-162.

Reuveni, O; Adato, Y, Kipnis, HL. (1972) study of new and rapid methods for the vegetative propagation of date palms. Date Grow Inst 49:17-24

Snedecor, D. M. and Cochran, W.G. (1989). Statistical Methods $6^{\text {th }}$. The lowa State University, Press, Ames, lowa, USA, $593 \mathrm{p}$.

Steel, R.G.D. and Torrrie, J. H. (1980). Reproduced from Principles and Procedures of Statistics. Printed with the Permission of C. I. Bliss, pp. 448-449.

Sultan, S. A. (1999). Study of some factors of the high mortality of date palm offshoots (Phoenix dactylifera) and it's overcome. Int. Conf. Date Palm. Assuit University, 9-11 November.

Tomlinson, P.B. (1990). The structural biology of palms. Oxford University Press, New York.

Woodward, A. W; and Bertel, B. (2005). Auxin: regulation, action, and interaction. Annals of botany, 95(5), 707-735.

Zaid, A. and Wet, P. F. de.( 2002). Date Palm Propagation. FAO Plant Production and Protection, 156: 73- 105.

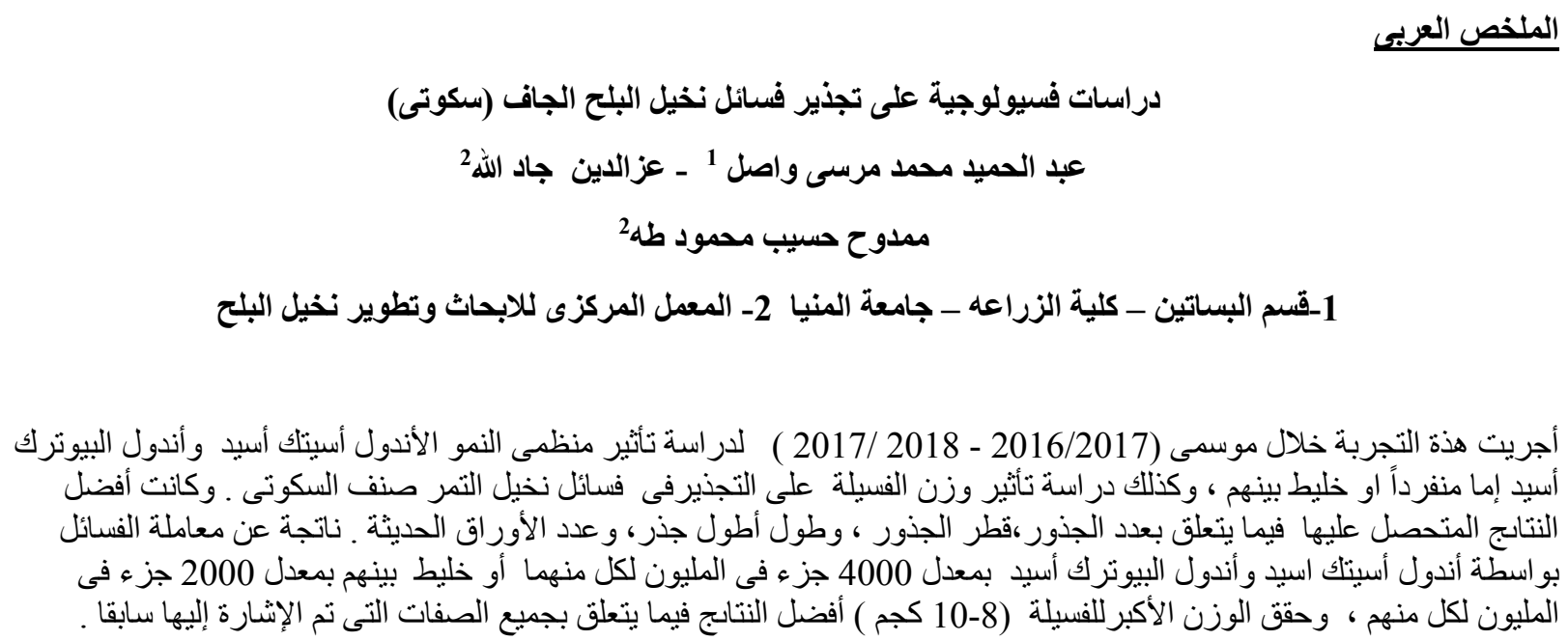


Wassel et al., 2021 